\title{
ADMINISTRATIVE OFFENCE IN THE FIELD OF INTELLECTUAL PROPERTY AS THE GROUND FOR ADMINISTRATIVE LIABILITY
}

The article deals with homogeneous group of administrative offences - administrative offences in the field of intellectual property as a basis of administrative liability. It is emphasized that the objective features of this administrative offence are its social harm, wrongfulness and punishment, and subjective ones are guilt and subjectivity. It is emphasized that only in the presence of all these features can one speak of qualifying an individual's act as an administrative offence and resolving the issue of bringing him to administrative liability. The definition of the term "administrative offence in the field of intellectual property" is proposed as envisaged by the legislation on administrative liability of socially harmful, unlawful, guilty act, committed by the subjects of such unlawful acts that encroach on the set of property and personal non-property rights to the intellectual results. It is established that all warehouses of administrative offences in the field of intellectual property (art. 51-2, 107-1, 156-3 (in the part concerning intellectual property objects), 164-3, 164-6, 164-7, 164-8, 164-9, 164-13) there are such elements as objective signs and subjective features, which in their unity form the composition of administrative offences of this group. It is noted that the only generic object of these administrative offences is the group of public relations of intellectual property, which are protected by the law on administrative liability, and the subject of this group of public relations are objects of intellectual property. It is proved that the objective side of administrative offences in the field of intellectual property is a set of ways of infringement of intellectual property rights. Attention is drawn to the fact that in practice the violation of intellectual property rights to different objects has different economic, social and legal consequences, and therefore the degree of their social harm is different, and therefore there is a need to differentiate administrative liability depending on the intellectual property. Subjective signs of the administrative offences of this group, which are represented by their subject, are established, and the subjective side is characterized by the fact that they are committed only intentionally.

Key words: administrative liability, administrative offence, administrative misconduct, intellectual property, objective part, ground for administrative liability, subjective part, area of intellectual property. 
Andrii Khridochkin, Head of the General Legal Sciences Department Dnipro Humanities University, Doctor of Law, Associate Professor https://orcid.org/0000-00019387-8864

Petro Makushev, Dean of the Law Faculty Dnipro Humanities University, Doctor of Law, Professor https://orcid.org/0000-00018693-1428

\section{Introduction}

The basis for the application of administrative liability for violation of intellectual property rights is a homogeneous group of administrative offences - administrative offences in the field of intellectual property. We believe that without a clear understanding of the essence of the concept of an administrative offence in intellectual property, an effective solution to the problems of intellectual property protection will be impossible, because its content determines the further directions of legal regulation in this field and is the basis for the legislative enforcement of the relevant legal actions. However, the disclosure of the concept of administrative offence in intellectual property requires, first of all, attention to the general theoretical concept and features of administrative offence, which, long before the legislative consolidation of this definition in the theory of administrative law, was actively developed by many scholars. The issue of defining the term "administrative offence" remains relevant today and is essential not only in theoretical but also in practical aspects. The importance of this area of research lies in the fact that the quality of interpretation of the concept of an administrative offence depends on the resolution of specific issues of administrative law, such as grounds for administrative liability, determining the range of its actors, as well as assessment of administrative offences. In addition, solving these problems is of great practical importance as it will facilitate the proper assessment of this type of offences and the application of administrative penalties for committing them.

\section{Analysis of recent research and publications}

The issue of the need to separate administrative offences in the field of intellectual property into a separate group of illegal acts is hardly considered by the administrative law science. It should be noted that part of the scientists (V.V. Halunko, T.A. Harbuz, O.M. Golovkova, I.H. Zaporozhets, H.S. Rymarchuk, N.V. Trotsyuk, Ye.V. Yurkova) do not consider to be justified the above arrangement of the rules on administrative liability for offences in the field of intellectual property in the structure of the Special part of the Code of Ukraine of Administrative Offences (hereinafter - the CUAO), 
and critically referring to the proposals to consolidate the rules of these articles in separate chapter. They argue that such changes will not only contribute solving any functional problems, but also capable of raising a number of additional issues. However, some of them (T.O. Harbuz, H.S. Rymarchuk) agree that the specifics of legal regulation of public relations in the field of intellectual property and because of the dual nature of objects of intellectual property does not allow to attribute the composition of these administrative offences to administrative offences affecting property, or to administrative offences in the fields of commerce, catering, services, finance and business.

Meanwhile, on the pages of scientific legal literature, there is an increasing number of proposals regarding the need to group articles that assume liability for unlawful encroachments on intellectual property into one structural element of the CUAO. For example, N.V. Trotsyuk noted that it is advisable to set aside a separate chapter in the CUAO for the Protection of Intellectual Property as a Special Legal Relationship Category, which will allow to take into account the peculiarity of the object of the unlawful encroachment. However, the authors of such proposals are not strictly unanimous. Thus, some experts (F.O. Kirilenko, V.A. Svyryda) argue for the need to isolate a special chapter on administrative offences in the field of intellectual property, while others (I.S. Kravchenko, A.H. Maidanevych) support their inclusion in the composition of the existing chapters of CUAO.

The article's objective is to formulate the concept and study of objective and subjective features of an administrative offence in intellectual property as a ground for administrative liability and development of proposals for improvement of legislative regulation of issues of administrative liability for this type of offences.

Methods of research. Philosophical, general scientific and special methods are used to achieve the article's objective. The dialectical method was used to make a comprehensive analysis of the administrative offence in the field of intellectual property. The application of methods of analysis, synthesis, systemic and structuralfunctional methods allowed to study the main components of an administrative offence in the field of intellectual property. The application of the structural-functional method facilitated a comprehensive study of the administrative-legal relations that arise in the process of violation of intellectual property rights.

\section{Basic content}

Art. 9 of the Code Of Ukraine of Administrative Offences (hereinafter CUAO) defines an administrative offence as unlawful, guilty (intentional or negligent) act or omission that encroaches on public order, property, citizens' rights and freedoms, in accordance with the established procedure of administration, and under which the law provides for administrative liability (Kodeks Ukrayiny' pro administraty'vni pravoporushennya, 1984, gruden 7). This article defines the general concept of "administrative offence", reveals its material content, legal nature and social essence, analyzing which can formulate the main features of administrative offence, in particular, and offences in intellectual property. Unlawful act in the theory 
of administrative law is recognized as an administrative offence if, in the aggregate, it contains all without exception objective and subjective features that distinguish them from lawful behaviour, as well as from other offences (crimes, disciplinary offences, civil law offences). Objective signs of an administrative offence are its social harm, wrongfulness and punishment, and subjective - guilt and subjectivity. Only in the presence of all these signs can one speak of qualifying an individual's act as an administrative offence and resolving the issue of bringing him/her to administrative liability.

We believe that these features are also characteristic of all administrative offences in intellectual property. And the first most significant feature of administrative offences in intellectual property is their social harmfulness, which consists in violation of intellectual property rights and causing damage (tangible and intangible) or threatening to cause them to the actors of those social relations that have arisen due to the use of intellectual creative activities and are protected by legislation on administrative liability. Public harmfulness of an administrative offence means that it causes harm to certain social relations, which are protected by legal rules: state and public order, property, citizens' rights and freedoms, established management order (Olishevs'ky'j, 2016). This harm can be both material and other (moral, organizational, etc.). The act or omission of the entity causes or threatens to cause harm to the objects of administrative and legal protection, in this case an encroachment on intellectual property rights, such as copyright or trademark rights (goods and services mark). Public harmfulness in these cases acts as an objective property of such offences and a real violation of the intellectual property rights relationship, constituting the "destruction of the social wrongdoing in the object - relations of the right to the intellectual property objects" (Selivanenko, 2013). The emergence, alteration or loss of social harm of such action is conditioned by the objective regularity of social development, inextricably linked with those socio-economic processes that take place in society.

Although today there is almost no debate among scholars about the nature and material properties of administrative offences, the aspect of its social danger and harmfulness remains debatable. Some authors (G.I. Petrov, A.M. Yakuba, M.S. Strogovich, Yu.P. Bytyak) exclude public danger from among the signs of administrative misconduct, while others acknowledge its spread both to crimes and to administrative offences. (O.Ye Lunyov, O.F. Shishkov, A.V. Seryogin). V.M. Potsiluiko considers the public danger of administrative misconduct as damaging to public relations, because in the linguistic sense, "dangerous" is harmful, capable of causing harm (Pocilujko, 2017). In our view, an administrative offence should be considered a socially harmful act with a degree of danger less than that found in the criminal offence. The Administrative Offences of Administrative Institution are not called "socially dangerous" - there are definitions such as "occurrence of harmful consequences", "act that harms...", "harm caused", etc. This makes it possible to characterize an administrative offence as socially harmful. That is, harm is an inherent feature of every administrative offence. 
As for the assessment of the public harm of administrative violations of intellectual property rights, it occurs at two levels: legislative (to date, the legislator has already placed most of the composition of these offences in the CUAO (Art. 51-2, 107$1,156-3$ (in the part concerning intellectual property), 164-3, 164-6, 164-7, 164$8,164-9,164-13$ ) and law enforcement (when public administration entities evaluate its degree in a specific in case of violation of intellectual property rights). Social harmfulness belongs to evaluation concepts, and the criterion of its degree is the objective and subjective features of the composition of the administrative offence in intellectual property: a specific object of intellectual property (the result of a person's literary and artistic activity, the result of his/her scientific and technical activity or the result individualization of goods (services) and their manufacturers), consequences, method of committing an administrative offence, guilt, motive and purpose. The damage caused by the violation in intellectual property finds its assessment in the sanction of the legal rules. Its high level is evidenced by the fines with a solid lower limit. Small amounts of damage are evidenced by the minor offence. Only the assessment of the whole set of features can reveal the gravity of the wrongful act - objective and real harm.

Administrative offences in intellectual property that directly cause damage are manifested in the real, material result (they are called offences with material composition). These include, in particular, the display and distribution of films without a state certificate for the right to distribute and display films (Articles 164-4 of the CUAO), the illegal distribution of copies of audiovisual works, phonograms, videograms, software and databases (Articles 164-9 CUAO). Administrative offences, which involve only danger or the possibility of causing harm and encroach on the legal form, are formal. Such are violations of mandatory rules that outline certain obligations and rights (e.g., infringement of intellectual property rights (art. 51-2 of the CUAO), violation of the legislation governing the production, export, import of disks for laser systems reading, exporting, importing of equipment or raw materials for their production (art. 164-13 of the CUAO).

The legal form of expression of social harmfulness of an administrative offence in intellectual property is its illegality, which indicates the illegality of such acts and their prohibition in the legislation on administrative liability. Unlawfulness is an intrinsic property of any administrative misconduct, which consolidates both the negative assessment of a certain act by the legislator, as a representative of the state, and the actual fact of leveling a legal order that determines the relevant attitude to the person-delinquent (Kalyenichenko, 2016). Unlawfulness, as a sign of an administrative offence in intellectual property, provides for a direct indication of this in the law, that is, it excludes the possibility of administrative liability for actions not provided for by the legislation on administrative offences. The administrative offence is only recognized as such unlawful act for which the lagislator provides for a special type of state coercion - administrative liability. The wrongfulness of an administrative offence is a violation of the mandatory rules established by 
the state. The administrative offence can be manifested in both unlawful action and unlawful inaction. In the first case, an act prohibited by law is committed, and in the second, the offender does not act, although the law requires him/her to take active actions. A sign of wrongfulness means that a right that is clearly established in a particular law, or whose violation is specifically enshrined in a special legislative act, is violated. Special legal acts defining the fundamental rights to intellectual property objects are "On copyright and related rights", "On protection of rights to inventions and utility models", "On protection of rights to plant varieties", etc.

Administrative unlawfulness is closely linked to public harm and is an objective manifestation of the real harmfulness of actions forpublic relationsin intellectual property and its legislative evaluation. In addition, administrative unlawfulness is a legal feature of social harm, and its degree determines the objective limits of unlawfulness, beyond which the question of criminalization of this act already arises (Py's'mens'ky'j, 2015). Allocation of administrative unlawfulness as a mandatory sign of an administrative offence is a concrete expression of the principle of legality in administrative law, since administrative liability is subject only to the person who committed a socially harmful act (the actor of misconduct), i.e. an act of specific, conscious and volitional behavior in the form of inaction, which is contrary to administrative law. Due to the presence of such a feature of administrative offences in intellectual property as unlawfulness, among all possible human acts in the specified area, the offences which are the subject of legal regulation of administrative law are distinguished.

Another mandatory feature of administrative offences in intellectual property, which is detected at the time of the offence and reflects its internal psychological content, is the presence of guilt. Thus, an administrative offence is not only a socially harmful, unlawful, but also a guilty act, that is, a result of the offender's will and mind. Guilt implies the presence of a person's own mental attitude to the relevant act and its consequences (Venger, 2015). Guilt forms are of great legal importance. Acting deliberately, the offender is aware of the unlawful nature of his/her act, anticipates and desires (direct intent) or knowingly permits (indirect intent) the occurrence of harmful consequences. An administrative offence may also be committed by negligence. Negligence is manifested in the form of overconfidence or negligence. Overconfidence is that a person anticipates the occurrence of a wrongful, harmful effect, but flippantly counts on its prevention. Negligence is that a person does not foresee the possibility of unlawful consequences, although under these circumstances he/she should and could have foreseen them.

This feature embodies the most important principle of administrative law the principle of subjective incrimination, that is, liability only for the guilt that arises under Art. 62 of the Constitution of Ukraine. Guilt is the mental attitude of a person to the act or omission he or she commits and their consequences, expressed in cases of infringement of intellectual property rights in the form of intent. It is the fault that determines the very presence of the subjective part of the administrative offence and to a large extent its content (Kozyurenko, 2016). 
Administrative offence in intellectual property is a unity of objective and subjective: act and mental (conscious and volitional) attitude to it. As an act cannot be disclosed out of touch with a person's mental attitude to it, so does the content of a mental attitude (guilt) not be determined out of touch with the nature of the act: the result of the intellectual creative activity that the person is harassing, the way of assault, the consequences and other objective features thereof. The guilt largely determines the nature of the act and the degree of its severity and is an important criterion for recognizing it as an administrative offence. The guilt is sometimes called the second substantive feature of an administrative offence and is its obligatory subjective feature. Without fault, there is no wrongdoing, and therefore there can be no administrative influence on one or another act against intellectual property.

Thus, the presence of the offender's guilt in one form or another is an important and necessary attribute of an administrative offence, which facilitates and clarify the assessment, determines the objectivity of the approach in determining the degree and type of aggravation charged to the perpetrator.

An important feature of an administrative offence in intellectual property is its administrative penality, which is understood to mean the threat of punishment for a given offence contained in administrative sanctions in due cases. A specific act can be recognized as an administrative offence only if its law provides for administrative liability (Chy'shko, 2015). As noted above, administrative misconduct is characterized by an internal trait - wrongfulness. This means that a certain act is defined by the legislator as prohibited and in the legislative act is indicated as an administrative offence. If a person commits actions that are prohibited by law or does not act in accordance with a legal act, there is an unlawful act that entails the use of administrative punishment - recovery. It is an outward sign of misconductpenality. Penality, by its very nature, stems from public harm and administrative wrongdoing: it therefore becomes administratively punishable, since it is socially harmful and provided for by administrative law as an offence.

Thus, the state of administrative punishment is a measure of administrative prevention, since it does not entail negative consequences for the offender, but performs only a preventive function, that is, aimed at preventing the repeated commitment of an administrative offence. Without any administrative sanction, it is impossible to combat any offences (Kolpakov, 2016). However, this does not mean that the punishment provided for in the sanction must necessarily be applied to the person who has committed the act formulated in the disposition of a particular article. A person recognized as an offender may be released from administrative liability. In some cases, the presence of all signs of an administrative offence in a person's act does not mean that the act automatically entails the administrative liability provided for by the Code of Administrative Offences. For example, according to Art. 18 of the Code of Administrative Offences, an act that contains all the features of an administrative offence is not such if it was committed in an emergency. Punishment, as a sign of administrative misconduct, provided for by 
Art. 51-2 of the Administrative Code in the form of a specific type of punishment: fine and confiscation of illegally manufactured products and equipment and materials intended for its manufacture. In some cases, particularly in cases of urgent need, the existence of all indications of administrative misconduct may not entail administrative liability. With regard to intellectual property, an urgent need may arise in the following cases: in the case of using the patented claims without the consent of the patentee to create a medicinal product necessary to preserve the life and health of the person (group of people) (My'ky'ty'n, 2016). However, the urgency does not allow for the use of procedures for obtaining the patent owner's license or compulsory license.

And the last sign of this type of administrative offence is their subjectivity. Administrative offences in $t$ intellectual property are acts committed by the subject of the offence, since not every person who commits a publicly harmful administrativeunlawful act is subject to administrative liability (Frolov, Vasy'l'yev, 2014). He/she should be aware of and manage his/her own actions, reach a certain age, and so on. Without this, a person cannot be recognized as an offender, and committing a socially harmful act - an administrative offence. The legal characteristic of the actor of administrative offences in intellectual property allows to determine the social and legal nature of their actors, to identify the causes and conditions that contribute to the development of administrative tort in the field of intellectual property, because, the correct determination of the legal status of the actor of this administrative offence, setting the level and directions of his/her professional training, social, financial status, as well as personal interests and preferences contributes to a complete and objective aligning administrative offences committed by participants in the analyzed field. In other words, the concept of "subjectiveness of an administrative offence in intellectual property" answers the question not only of who can commit a particular offence under specific circumstances, but also in what socio-legal status and using what professional, personal and unlawful behaviour of a specific participant of intellectual property relations may be formed.

\section{Conclusions}

Thus, an administrative offence in intellectual property can be defined as envisaged by the legislation on administrative liability socially harmful, unlawful, guilty act committed by the actor of such unlawful acts that encroach on the set of property and personal non-property rights to the results of conscious intellectual artistic activity. If a person commits an administrative offence in intellectual property containing the composition of an administrative violation this will be ground for bringing $\mathrm{him} / \mathrm{her}$ to administrative liability and applying to it appropriate administrative penalties. depending on the type of offence in relation to specific intellectual property objects, liability for violation of rights for which are established by law.

We believe that an urgent measure to improve the legal framework for the protection of intellectual property is the allocation of relevant administrative offences in a separate chapter of the Special part of the CUAO. Certainly, 
the integration of rules is not capable of eliminating all the difficulties, since there are also problems that, as the practice shows, usually come to the fore - problems related to the enforcer's personality. But this does not mean that, since there are enforcement problems, the law should not be improved. After all, to achieve a truly effective result of improving the administrative and legal protection of intellectual property, just combining the relevant articles of law in a separate chapter will not be enough. The new structural element of the CUAO should be based on the current concept of intellectual property protection and have an appropriate structure that meets the current requirements.

\section{Bibliography:}

1. Кодекс України про адміністративні правопорушення від 7 грудня 1984 р. URL: http://www.zakon.rada.gov.ua/go/80731-10.

2. Олішевський О.В. Соціально шкідливі наслідки сприйняття інформації, що містить пропаганду культу насильства і жорстокості. Форум права. 2016. № 2. С. 135-139.

3. Селіваненко В.В. Форми порушення та захист прав суспільства на об'єкти інтелектуальної власності у сфері охорони здоров'я. Часопис Київського університету права. 2013. № 3. С. 223-228.

4. Поцілуйко В.М. Наукова доцільність порівняльно-правового дослідження заходів забезпечення провадження в кримінальних справах та справах про адміністративні правопорушення. Вісник Чернівецького факультету Нациіонального університету "Одеська юридична академія». 2017. Вип. 4. С. 219-229.

5. Калєніченко Л.І. Об'єктивно протиправне діяння як фактична підстава юридичної відповідальності (аналіз галузевого законодавства). Вісник Харківського національного університету внутрішніх справ. 2016. Вип. 4. С. 19-28.

6. Письменський Є.О. Реалізація кримінально-правової політики шляхом криміналізації та декриміналізації: аналіз поточних законодавчих ініціатив. Часопис Київського університету права. 2015. № 1. С. 230-234.

7. Венгер Ю.В. Вина як суб'єктивна підстава адміністративної відповідальності юридичної особи за вчинене правопорушення у сфері стандартизації. Науковий вісник Міжнародного гуманітарного університету. Серія : Юриспрудениія. 2015. Вип. 13(1). С. 85-87.

8. Козюренко Р.С. Заходи адміністративної відповідальності за вчинені правопорушення: поняття та класифікація. Вісник Національного університету «Львівська політехніка». Юридичні науки. 2016. № 845. С. 94-98.

9. Чишко К.О. Адміністративно-правова кваліфікація та кваліфікація адміністративного правопорушення (проступку): поняття, ознаки, передумови. Вісник Харківського начіонального університету внутрішніх справ. 2015. Вип. 3. С. 150-158.

10. Колпаков В.К. Фактичні ознаки та юридичний склад адміністративного проступку: поняття та розмежування. Вісник Запорізького національного університету. Юридичні науки. 2016. № 3. С. 160-170.

11. Микитин В.І. Окремі аспекти наслідків порушення прав інтелектуальної власності. Науковий вісник Херсонського державного університету. Серія : Юридичні науки. 2016. Вип. 2(1). С. 79-83.

12. Фролов О.С., Васильєв І.В. Зміст та обсяг концепту «суб’ єкт адміністративного правопорушення». Держава і право. Юридичні і політичні науки. 2014. Вип. 66. С. 105-117. 


\section{References:}

1. Kodeks Ukrayiny' pro administraty'vni pravoporushennya (1984, gruden 7 ). URL: http://www.zakon.rada.gov.ua/go/80731-10 [in Ukrainian].

2. Olishevs'ky'j O.V. (2016). Social'no shkidly'vi naslidky' spry'jnyattya informaciyi, shho misty't' propagandu kul'tu nasy'l'stva i zhorstokosti. Forum prava. 2. 135-139 [in Ukrainian].

3. Selivanenko V.V. (2013). Formy' porushennya ta zaxy'st prav suspil'stva na ob'yekty' intelektual'noyi vlasnosti u sferi oxorony' zdorov'ya. Chasopy's Ky'yivs'kogo universy'tetu prava. 3. 223-228 [in Ukrainian].

4. Pocilujko V.M. (2017). Naukova docil'nist' porivnyal'no-pravovogo doslidzhennya zaxodiv zabezpechennya provadzhennya v kry'minal'ny'x spravax ta spravax pro administraty'vni pravoporushennya. Visny'k Chernivecz'kogo fakul'tetu Nacional'nogo universy'tetu "Odes'ka yury'dy'chna akademiya". 4. 219-229 [in Ukrainian].

5. Kalyenichenko L.I. (2016). Ob'yekty'vno proty'pravne diyannya yak fakty'chna pidstava yury'dy'chnoyi vidpovidal'nosti (analiz galuzevogo zakonodavstva). Visny'k Xarkivs'kogo nacional'nogo universy'tetu vnutrishnix sprav. 4. 19-28 [in Ukrainian].

6. Py's'mens'ky'j Ye.O. (2015). Realizaciya kry'minal'no-pravovoyi polity'ky' shlyaxom kry'minalizaciyi ta dekry'minalizaciyi: analiz potochny'x zakonodavchy'x iniciaty'v. Chasopy's Ky'yivs'kogo universy'tetu prava. 1. 230-234 [in Ukrainian].

7. VengerYu.V.(2015). Vy'nayak sub'yekty'vna pidstava administraty'vnoyi vidpovidal'nosti yury'dy'chnoyi osoby' za vchy'nene pravoporushennya u sferi standarty'zaciyi. Naukovy'j visny'k Mizhnarodnogo gumanitarnogo universy'tetu. Seriya : Yury'sprudenciya. 13(1). 85-87 [in Ukrainian].

8. Kozyurenko R.S. (2016). Zaxody' administraty'vnoyi vidpovidal'nosti za vchy'neni pravoporushennya: ponyattya ta klasy'fikaciya. Visny'k Nacional'nogo universy'tetu 'L'vivs'ka politexnika". Yury'dy'chni nauky'. 845. 94-98 [in Ukrainian].

9. Chy'shko K.O. (2015). Administraty'vno-pravova kvalifikaciya ta kvalifikaciya administraty'vnogo pravoporushennya (prostupku): ponyattya, oznaky', peredumovy'. Visny'k Xarkivs'kogo nacional'nogo universy'tetu vnutrishnix sprav. 3. 150-158 [in Ukrainian].

10. Kolpakov V.K. (2016). Fakty'chni oznaky' ta yury'dy'chny'j sklad administraty'vnogo prostupku: ponyattya ta rozmezhuvannya. Visny'k Zaporiz'kogo nacional'nogo universy'tetu. Yury'dy'chni nauky'. 3. 160-170 [in Ukrainian].

11. My'ky'ty'n V.I. (2016). Okremi aspekty' naslidkiv porushennya prav intelektual'noyi vlasnosti. Naukovy'j visny'k Xersons 'kogo derzhavnogo universy'tetu. Seriya : Yury'dy'chni nauky'. 2(1). 79-83 [in Ukrainian].

12. Frolov O.S., Vasy'l'yev I.V. (2014). Zmist ta obsyag konceptu ,sub'yekt administraty'vnogo pravoporushennya". Derzhava i pravo. Yury'dy'chni i polity'chni nauky'. 66. 105-117 [in Ukrainian]. 


\title{
АДМІНІСТРАТИВНЕ ПРАВОПОРУШЕННЯ У СФЕРІ ІНТЕЛЕКТУАЛЬНОЇ ВЛАСНОСТІ ЯК ПІДСТАВА АДМІНІСТРАТИВНОЇ ВІДПОВІДАЛЬНОСТІ
}

\author{
Андрій Хрідочкін, \\ завідувач кафедри загально-правових дисциплін \\ Дніпровського гуманітарного університету, \\ доктор юридичних наук, доцент \\ https://orcid.org/0000-0001-9387-8864
}

\author{
Петро Макушев, \\ декан юридичного факультету \\ Дніпровського гуманітарного університету, \\ доктор юридичних наук, професор \\ https://orcid.org/0000-0001-8693-1428
}

У статті розглянуто однорідну групу адміністративних правопорушень адміністративних правопорушень у сфері інтелектуальної власності як основи адміністративної відповідальності. Підкреслюється, щзо об'єктивними ознаками цуього адміністративного правопорушення є його суспільна шкода, протиправність та покарання, а суб 'єктивними - винність та суб 'єктивність. Підкреслюється, шуо лише за наявності всіх цуих ознак можна говорити про кваліфікацію діяння фізичної особи як адміністративного правопорушення та вирішення питання про притягнення ї до адміністративної відповідальності. Визначення терміна «адміністративне правопорушення у сфері інтелектуальної власності» пропонується таким, щчо передбачено законодавством про адміністративну відповідальність за суспільно икідливий, протиправний, винний вчинок, вчинений суб'єктами таких протиправних дій, що посягають на сукупність майна та особисті немайнові права на інтелектуальні результати. Встановлено, щзо всі склади адміністративних правопорушень у сфері інтелектуальної власності (cm. 51-2, 107-1, 156-3 (у частині, щуо стосується об 'єктів інтелектуальної власності), 164-3, 164-6, 164-7, 164-8, 164-9, 164-13) існують такі елементи, як об 'єктивні ознаки та суб 'єктивні ознаки, які у своїй єдності утворюють склад адміністративних правопорушень ијієі групи. Зазначається, щу єдиним родовим об'єктом ичих адміністративних правопорушень $\epsilon$ група суспільних відносин інтелектуальної власності, які охороняються законом про адміністративну відповідальність, а предметом иієєї групи суспільних відносин є об'єкти інтелектуальної власності. Доведено, щчо об'єктивною стороною адміністративних правопорушень у сфері інтелектуальної власності є сукупність способів порушення прав інтелектуальної власності. Звертається увага на те, щзо на практиці порушення прав інтелектуальної власності на різні об’єкти має різні економічні, сочіальні та правові наслідки, а тому ступінь їхньої соціальної икоди різна, та існує необхідність диференціювати адміністративну відповідальність залежно від інтелектуальної власності. Суб'єктивні ознаки адміністративних правопорушень иієї групи, які представлені їх суб'єктом, встановлюються, а суб'єктивна сторона характеризується тим, шуо вони вчинені лише навмисно.

Ключові слова: адміністративна відповідальність, адміністративне правопорушення, адміністративний проступок, інтелектуальна власність, об'єктивні ознаки, підстава адміністративної відповідальності, суб'єктивні ознаки, сфера інтелектуальної власності. 